\title{
Rates and predictors of adherence and retention for antiretroviral therapy among HIV-positive adults in Enugu, Nigeria
}

\section{Onyinye Hope Chime ${ }^{1,2}$,Edmund Onyemaechi Ndibuagu ${ }^{1,2}$, Chinonyelu Jennie Orji ${ }^{1}$}

1. Department of Community Medicine, Enugu State University Teaching Hospital, Enugu, Nigeria

2. Department of Community Medicine, Enugu State University College of Medicine, Enugu, Nigeria

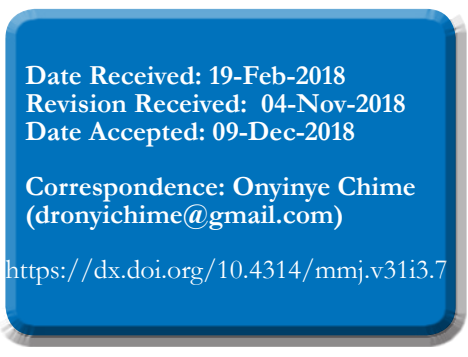

\begin{abstract}
Background
HIV infection and AIDS are majorpublic health challenges in Nigeria, a country with one of the highest rates of new infection in sub-Saharan Africa and the second largest HIV epidemic in the world.Non-adherence to medication and defaulting from treatment are the two major challenges faced by anti-retroviral therapy (ART) programs in resource-constrained settings. This study was undertaken to determine the rate and predictors of adherence to medication and retention among people living with HIVin Enugu State, Nigeria. Methods

This was a cross-sectionalretrospective study conducted among adults living with HIV(PLHIV) receiving ARTs in eightcomprehensive health facilities in Enugu, Nigeria. We used self-reported adherence and recorded clinic visits to assess adherence and retention, respectively. Descriptive statistics (frequencies, proportions, mean and standard deviation) and regression analysis were then conducted to identify the association between adherence, retention and demographic and health-related factors.

Results

The mean age of respondents was $38.5 \pm 9.8$ years. Predictors of good adherence to medication includedbeing male(adjusted odds ratio [AOR]:2.08; 95\% confidence interval [CI]:1.12-3.85), having been on anti-retroviral medications for more than 5 years (AOR:1.92; 95\% CI: 1.17-3.16), the non-consumption of alcohol(AOR: 3.67; 95\% CI: 2.01-6.70),not usingtraditional medicine (AOR: 2.76; 95\% CI:1.33-5.73) and having a baseline CD4count exceeding 500 cells/ $\mu$ (AOR: 5.67; 95\% CI: 1.32-24.32).Adequate retention was predicted by being resident in the urban area (AOR: 1.90; 95\% CI: 1.17-3.06). Being away from home (41.8\%) and forgetfulness $(35.0 \%)$ were reported as the major reasons for missing medication.

Conclusion

The rates of adherence and retention found in this study were similar to those reported forother resource-limited settings. Health education and behavioural modification interventions should be intensified to reduce the consumption of alcohol and the use of traditional medicine by people living with HIV. Identifying other factors may help to design effective strategies to ensure that people living with HIV adhere to their medications and remain in care.
\end{abstract}

\section{Key Words}

Adherence, retention, predictors, PLHIV, Enugu State, Nigeria

\section{Introduction}

Sub-Saharan Africa, home to over $10 \%$ of the world's population, remains the worst HIV-affected region in the world. In fact, this geographical area is home to approximately $70 \%$ of all people living with HIV (PLHIV) globally ${ }^{1}$. While the number of people newly diagnosed with HIV is falling, both HIV and AIDS remain major public health challenges in Nigeria, the country with the second largest HIV epidemic in the world ${ }^{2}$. Findings from the 2014 HIV National Sentinel Survey showed that Nigeria, Africa's most populous nation with a population of 186 million, had an HIV prevalence of $3.0 \%$.ranging from $0.9 \%$ to $15.4 \%$ across different zones ${ }^{2,3}$. Furthermore, thissurvey showed that 1.6 million women were living with HIV compared with 1.4 million men $^{2,3}$. The magnitude of the HIV epidemic, and the complexity of its chronicity, however, represent major challenges to healthcare delivery systems in both resource-rich and resourceconstrained settings ${ }^{4}$. In resource-constrained settings, in which healthcare services are not well developed, there are two major challenges faced by anti-retroviral therapy (ART) programs:poor adherence to treatment and defaulting from treatment ${ }^{5}$.

Adherence has been difficult to sustain for patients receiving highly active anti-retroviral therapy (HAART) across the globe $^{6}$. The meanrate of adherence to ART is approximately $70 \%$, despite the fact that long-term viral suppression requires near-perfect adherence ${ }^{7}$. On the other hand, poor adherence compromises the efficacy of treatment, making this a critical public health issue ${ }^{8}$. As one of the major predictors of progression to AIDS and death after CD4 count, poor adherence is also associated with the development of drugresistant viral strains and virological failure ${ }^{7,9,10}$. The results of a 2006 meta-analysis of ART adherence showed that, on average, $23 \%$ of patients in studies from sub-Saharan Africa did not achieve adequate adherence, with the proportion of non-adherent patients ranging from $2 \%$ to $70 \%{ }^{11}$. 
Despite the widely acknowledge scale-up in the use of ARTs, retaining patients in care remains a well-documented global challenge and has undermined efforts to enhance treatment outcomes ${ }^{12,13}$. Patient retention is a function of attrition which includes deaths, patients who are lost-tofollow-up (LTFU) and those who stop treatment.LTFU is the most common cause of attrition, followed by death ${ }^{12}$. Furthermore, LTFU has been shown to contribute to poorer health outcomes for patients, constitutes a serious form of resource wastage, and can promoteHIV drug resistance ${ }^{14}$. In 2007, a meta-analysis of ART programs in Africa showed a retention of approximately $60 \%$ and $76 \%$ of patients on ART at the end of 2 years and 3 years, respectively ${ }^{15}$. Similar findings were reported in an updated meta-analysis of 39 cohorts from sub-Saharan Africa in 2011

Many barriers to adherence are common to both developed and developing settings, such as fear of disclosure. Other barriers are unique to studies conducted in the developing world, such as financial constraints (cost of drugs and/or transport) and others, such as stigma, a feeling of being healthy and forgetfulness ${ }^{5,16,17}$. Other factors can also make it more difficult for patients to adhere to treatment, includingmental illness, the complexity of drug regimes, the side effects of medication, active alcohol use, substance abuse and the non-disclosure of HIV status ${ }^{6,18,19}$. Factors such as increased duration on ART, male gender, an age of less than 15 years and a World Health Organization (WHO) classification of stage III and IV have been shown to be significantly associated with retention ${ }^{20}$. Based on a study population in south-eastern Nigeria, Onoka et al. reported that being male, having a CD4 countless than $200 / \mu l$ and being treated by a public hospitalwere good predictors of retention-in-care ${ }^{20}$. In another study, Eguzo et al. found that baseline CD4 count, the year of enrolment and drug combination were significant predictors of retention ${ }^{14}$. With the positive strides already gained in the fight against AIDS over recent years, the paradigm of HIV care has now shifted to theestablishment of a continuum of care among PLHIV. Although research has shown that adequate ART adherence rates can be achieved in resource-poor settings ${ }^{11}$, there are concerns that adherence to ART in such settings may decline as access to treatment increases ${ }^{10}$. The present studycollaborated with several healthcare facilities within Enungu State Nigeria and aimed to investigate adherence to medication and retention among PLHIV. Findings from this study will aid the planning and implementation of intervention programs so that we can scale-up ART adherence and retention of PLHIV in Enugu State Nigeria.

\section{Methods}

\section{Study setting}

Enugu state is one of the five states in south-eastern Nigeria, with a population of $3,257,298$ people ${ }^{22}$, three senatorial zones and 17 local government areas (which serve as administrative units for the state). The ART program was introduced into this state in 2004 and first began to provide free drugs to patients in 2006. In Enugu state, ART services are now offered in 21 comprehensive ART sites, in both public and private health institutions. This study was conducted in eight comprehensive health facilities in Enugu state: Mother of Christ Specialist Hospital, University of Nigeria Teaching Hospital, Annunciation Specialist Hospital, Enugu State University Teaching Hospital, Nsukka District Hospital, Bishop Shanahan Hospital, Udi District Hospital and General Hospital Nsukka.

\section{Study design, population and sampling}

This study combined both cross-sectional and retrospective study designs involving PLHIV who accessed care in comprehensive health facilities in Enugu state. We included all PLHIV that were over 18 years of age and had been onHAART for at least 1 year prior to the study commencing. We excluded patients who refused to provide consent, whose records were incomplete or missing, or who were in HIV clinical stage III or IV and in a generally poor clinical state at presentation, usually with complicated AIDS-defining illness. The minimum sample size for the study was determined based on the expected proportion of adherence to ART among PLHIV in a previous study $(75 \%)^{5}$; the calculations involved the use of Fisher's statistical formula ${ }^{23}$. However, in order to increase the validity of the study, a sample size of 840 was used, with a relative precision of $5 \%$ and a confidence interval of $95 \%$. We then compiled a list of patients attending ART clinics using files from the medical records department of the eight selected health facilities. We used this data to then determine the sampling frame for the study.Theeight facilities were selected proportionately from the three senatorial zones. The sample size was proportionally allocated to the facilities based on their patient load. A systematic sampling technique was then used to select the study participants as they presented for their routine clinic visits.

\section{Data collection}

The study lasted for 6 weeks (August to September 2016). Data was collected from study participants using two approaches; a pre-tested semi-structured intervieweradministered questionnaire designed by the principal researcher, and medical records. The questionnaire contained a section relating to socio-demographic information and another section on self-reported adherence. Additional questions were developed to acquire responses peculiar to this study such as disclosure, social habitsand theHIV status of partner.We reviewed the medical records of each participant to ascertain retention over a period of 1 year prior to the study. Routine health data were extracted from medical records, includingthe year of HIV diagnosis, the duration on HAART, the type of regimen, dosing frequency and the regularity of routine clinic visits. The questionnaire was pretested among 42 randomly selected PLHIV from a health facility in Agbani district, which was not selected for the main study. Ambiguities or deficiencies in the study instruments were then revised. Ethical approval was obtained from the Health Research and Ethics Committee of Enugu State University Teaching Hospital, Enugu. The study was also approved by theState Ministry of Health and the Heads of the health facilities involved. Written consent was secured from each participant and anonymity was assured.

\section{Measurement of variables}

We used the pharmacy records, regimen type and dosing frequency to estimate the total number of doses expected and delivered within a 1 -month period. In order to determine self-reported adherence, we asked our participants the following question:'How many pills were you unable to take in the past 28 days?' Self-reported adherence was then ascertained by calculating the proportion (\%) of medication (pills) taken over 28 days divided by the number of pills prescribed within the same period. In this study, adherence 
was classified as either good or poor. Good adherence was scored as ' 1 ' while poor adherence was scored as ' 0 '. Participants who achieved an adherenceof less than 95\% were classified as having poor adherence, while those withan adherence of $95 \%$ and abovewere classified as having good adherence; these classifications were based on established
WHO definitions ${ }^{24}$.

Retention was assessed using the medical records of each participantover a period of 1 year prior to the study commencing. Participants who were absent from treatment for at least 90 days (3 months) from the last given refill or appointment date were considered LTFU and scored as ' 0 '

Table 1. Socio-demographic characteristics of respondents $(\mathrm{N}=840)$

\begin{tabular}{|c|c|c|}
\hline Variable & Frequency & Percenta \\
\hline $\begin{array}{l}\text { Age of respondents } \\
\text { Mean } \pm(S D)\end{array}$ & $38.5 \pm 9.8$ & \\
\hline $\begin{array}{l}\text { Age in groups } \\
<30 \text { years } \\
30-39 \text { years } \\
40-49 \text { years } \\
\geq 50 \text { years }\end{array}$ & $\begin{array}{l}136 \\
353 \\
228 \\
123\end{array}$ & $\begin{array}{l}16.2 \\
42.0 \\
27.1 \\
14.6\end{array}$ \\
\hline $\begin{array}{l}\text { Gender } \\
\text { Male } \\
\text { Female }\end{array}$ & $\begin{array}{l}199 \\
641\end{array}$ & $\begin{array}{l}23.7 \\
76.3\end{array}$ \\
\hline $\begin{array}{l}\text { Level of Education } \\
\text { No formal education } \\
\text { Primary education } \\
\text { Secondary education } \\
\text { Tertiary education }\end{array}$ & $\begin{array}{c}44 \\
312 \\
362 \\
122\end{array}$ & $\begin{array}{c}5.2 \\
37.1 \\
43.1 \\
14.5\end{array}$ \\
\hline $\begin{array}{l}\text { Employment status } \\
\text { Self employed } \\
\text { Salary earners } \\
\text { Unemployed/Student }\end{array}$ & $\begin{array}{c}623 \\
119 \\
98\end{array}$ & $\begin{array}{l}74.2 \\
14.2 \\
11.7\end{array}$ \\
\hline $\begin{array}{l}\text { Area of Residence } \\
\text { Rural } \\
\text { Urban }\end{array}$ & $\begin{array}{l}553 \\
287\end{array}$ & $\begin{array}{l}65.8 \\
34.2\end{array}$ \\
\hline $\begin{array}{l}\text { Socio-Economic Status } \\
\text { Low socio-economic status } \\
\text { High socio-economic status }\end{array}$ & $\begin{array}{l}425 \\
415\end{array}$ & $\begin{array}{l}50.6 \\
49.4\end{array}$ \\
\hline $\begin{array}{l}\text { HIV Status of partner } \\
\text { Unknown } \\
\text { Negative } \\
\text { Positive }\end{array}$ & $\begin{array}{c}\mathrm{n}=742 \\
241 \\
235 \\
266\end{array}$ & $\begin{array}{l}32.5 \\
31.7 \\
35.8\end{array}$ \\
\hline $\begin{array}{l}\text { Mode of transport } \\
\text { Taxi/Bus } \\
\text { Tricycle/Okada } \\
\text { Personal car } \\
\text { Walk }\end{array}$ & $\begin{array}{c}630 \\
170 \\
26 \\
14\end{array}$ & $\begin{array}{c}75.0 \\
20.2 \\
3.1 \\
1.7\end{array}$ \\
\hline
\end{tabular}

Approximate cost of transport to health facility

\section{(Naira)}

Mean \pm SD

Median

Minimum

Maximum

Estimated time to reach the facility (Minutes)

Mean \pm SD

Median

Minimum

Maximum

\section{Alcohol intake}

No

Yes
$601.3 \pm 691.4$

400

80

5000

$69 \pm 45$

60

10

240
16.2

14.6

23.7

76.3

5.2

37.1

43.1

14.5

74.2

14.2

1.7

65.8

34.2

50.6

49.4

32.5

31.7

35.8

75.0

20.2

1.7 
while those that reported at least once within 3 months were scored as '1'20. The quarterly visits (four visits annually) were summated over the year. For the purpose of this study, retention was categorizedas either adequate or inadequate. Adequate retention was scored as' 1 ' while inadequatewas scored $a^{\prime}{ }^{\prime} 0$ '. Participants with a total of four visits were categorized as having adequate retention while those who made less than fourvisits were categorized as having inadequate retention.To avoid recall bias, we extracted this information from thehospital records of each participant.

\section{Data analysis}

Data cleaning and editing were performed manually and were designed todetect omissions and ensure uniform coding. Data entry and analysis were performed using the Statistical Package for Social Sciences (SPSS) version 22. Frequencies and proportions were derived for categorical variables

Table 1 Cont..

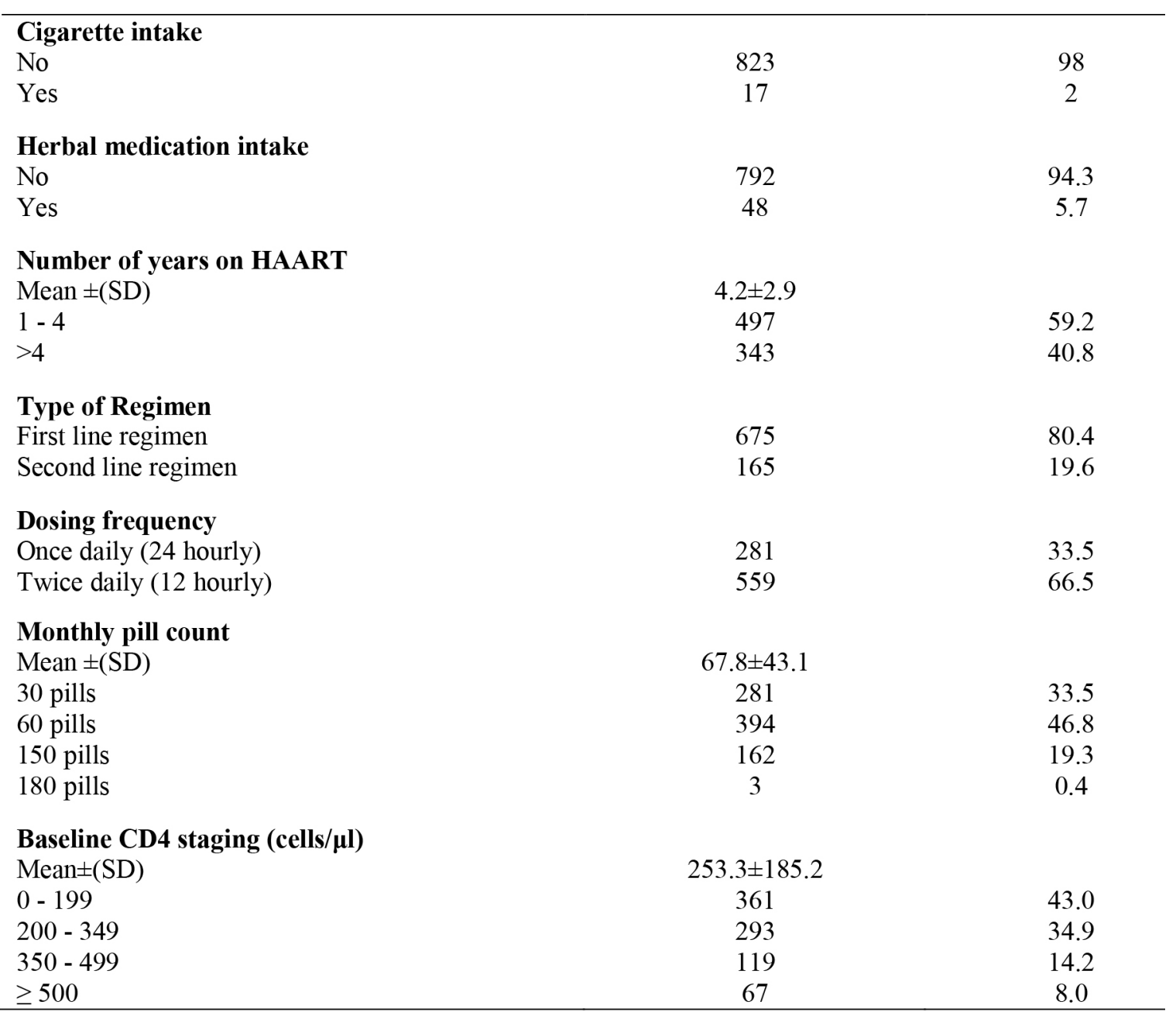

Table 2. Adherence and retention rates of PLHIV in Enugu

\begin{tabular}{lcc}
\hline Variable & Frequency & Percentage \\
\hline Adherence $\geq \mathbf{9 5 \%}$ & 752 & 89.5 \\
Adequate Retention & 732 & 87.1 \\
\hline
\end{tabular}

and analysed using the chi-square test and Student's t-test. Multivariate analysis, using binary logistic regression,was also used to predict the probability of occurrence for each outcome variable. Results are reported asodds ratios and $95 \%$ confidence intervals; the level of significance was set to 0.05 . Variables showing a P-value $<0.2$ in the bivariate analysis were subsequently entered into a multivariate binary logistic regression model to determine predictors of medication adherence and retention.

In addition, we also determined the socio-economic status (SES) index for each patient usingprincipal component analysis (PCA) and Stata statistical software version 10. The indicator variables used for PCA were (1) estimated monthly household incomeand (2) ownership of ten household modern assets, including radio, plasma television, refrigerator, cable television, electric fan, air conditioner, motor vehicle, 
Table 3. Predictors of adherence to ART among PLHIV in Enugu

\begin{tabular}{|c|c|c|c|c|}
\hline Variable & $\begin{array}{c}\text { Adherence } \\
\text { Yes }\end{array}$ & $\begin{array}{c}\text { Adherence } \\
\text { No }\end{array}$ & p-value* & $\operatorname{AOR}[95 \% \mathrm{CI}] * *$ \\
\hline $\begin{array}{l}\text { Age in groups } \\
<30 \text { years } \\
30-39 \text { years } \\
40-49 \text { years } \\
\geq 50 \text { years }\end{array}$ & $\begin{array}{l}120(16.0) \\
311(41.4) \\
206(27.4) \\
115(15.3)\end{array}$ & $\begin{array}{c}16(18.2) \\
42(47.7) \\
22(25.0) \\
8(9.1)\end{array}$ & 0.356 & NA \\
\hline $\begin{array}{l}\text { Gender } \\
\text { Male } \\
\text { Female }\end{array}$ & $\begin{array}{l}183(24.3) \\
569(75.7)\end{array}$ & $\begin{array}{l}16(18.2) \\
72(81.8)\end{array}$ & 0.199 & $\begin{array}{c}2.08[1.12-3.85] \\
1\end{array}$ \\
\hline $\begin{array}{l}\text { Education of respondent } \\
\text { No Formal Education } \\
\text { Primary Education } \\
\text { Secondary Education } \\
\text { Tertiary Education }\end{array}$ & $\begin{array}{c}42(5.6) \\
280(37.2) \\
320(42.6) \\
110(14.6)\end{array}$ & $\begin{array}{l}2(2.3) \\
32(36.4) \\
42(47.7) \\
12(13.6)\end{array}$ & 0.530 & NA \\
\hline $\begin{array}{l}\text { Employment status of } \\
\text { respondent } \\
\text { Self employed } \\
\text { Salary earners } \\
\text { Unemployed/student }\end{array}$ & $\begin{array}{l}555(89.1) \\
107(89.9) \\
90(91.8)\end{array}$ & $\begin{array}{c}68(10.9) \\
12(10.1) \\
8(8.2)\end{array}$ & 0.702 & NA \\
\hline $\begin{array}{l}\text { Number of years on HAART } \\
>4 \\
1-4\end{array}$ & $\begin{array}{l}317(92.4) \\
435(87.5)\end{array}$ & $\begin{array}{l}26(7.6) \\
62(12.5)\end{array}$ & 0.023 & $\begin{array}{c}1.92[1.17-3.16] \\
1\end{array}$ \\
\hline $\begin{array}{l}\text { Area of residence } \\
\text { Urban } \\
\text { Rural }\end{array}$ & $\begin{array}{c}261(90.9) \\
491(88.8)\end{array}$ & $\begin{array}{l}26(9.1) \\
62(11.2)\end{array}$ & 0.334 & NA \\
\hline $\begin{array}{l}\text { Socio-economic status } \\
\text { Low socio-economic status } \\
\text { High socio-economic status }\end{array}$ & $\begin{array}{l}380(89.4) \\
372(89.6)\end{array}$ & $\begin{array}{l}45(10.6) \\
43(10.4)\end{array}$ & 0.915 & NA \\
\hline $\begin{array}{l}\text { Alcohol Intake } \\
\text { No } \\
\text { Yes }\end{array}$ & $\begin{array}{c}685(91.1) \\
67(8.9)\end{array}$ & $\begin{array}{l}66(75.0) \\
22(25.0)\end{array}$ & $<0.001$ & $\begin{array}{c}3.67[2.01-6.70] \\
1\end{array}$ \\
\hline $\begin{array}{l}\text { Cigarette/Tobacco intake } \\
\text { No } \\
\text { Yes }\end{array}$ & $\begin{array}{c}737(98.0) \\
15(2.0)\end{array}$ & $\begin{array}{c}86(97.7) \\
2(2.3)\end{array}$ & 0.861 & NA \\
\hline $\begin{array}{l}\text { Traditional medicine intake } \\
\text { No } \\
\text { Yes }\end{array}$ & $\begin{array}{c}717(95.3) \\
35(4.7)\end{array}$ & $\begin{array}{l}75(85.2) \\
13(14.8)\end{array}$ & $<0.001$ & $\begin{array}{c}2.76[1.33-5.73] \\
1\end{array}$ \\
\hline $\begin{array}{l}\text { Cost of transportation to health } \\
\text { facility (Naira) } \\
\leq 400 \\
>400\end{array}$ & $\begin{array}{l}413(57.0) \\
312(43.0)\end{array}$ & $\begin{array}{l}47(56.6) \\
36(43.4)\end{array}$ & 0.953 & NA \\
\hline $\begin{array}{l}\text { Baseline CD4 staging }(\text { cells } / \boldsymbol{\mu L}) \\
\geq 500 \\
350-499 \\
200-349 \\
0-199\end{array}$ & $\begin{array}{l}65(8.6) \\
106(14.1) \\
268(35.6) \\
313(41.6)\end{array}$ & $\begin{array}{c}2(2.3) \\
13(14.8) \\
25(28.4) \\
48(54.5)\end{array}$ & 0.041 & $\begin{array}{c}5.67[1.32-24.32] \\
1.43[0.72-2.81] \\
1.78[1.05-3.03] \\
1\end{array}$ \\
\hline
\end{tabular}

washing machine, gas cooker and electric iron. Weights were assigned to the different variables and categories. The wealth index was calculated using the 'balanced weight' of the variables. Each respondent was categorized into 2; either a low or high SES index based on the wealth index score of their household.

\section{Results}

Table 1shows the socio-demographic characteristics of our

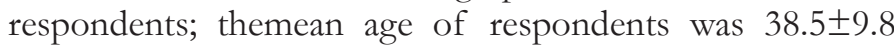
years. The highest proportion of respondents were aged 30-39 years. The majority of respondents were females $(76.3 \%)$, which reflects the present demographics of patients receiving $\mathrm{HIV} / \mathrm{AIDS}$ care and treatment in Nigeria. Most 
Table 4. Predictors of retention

\begin{tabular}{|c|c|c|c|c|}
\hline Variable & $\begin{array}{c}\text { Retention } \\
\text { Yes }\end{array}$ & $\begin{array}{l}\text { Retention } \\
\text { No }\end{array}$ & p-value* & AOR $[95 \% \mathrm{CI}]^{* *}$ \\
\hline \multicolumn{5}{|l|}{ Age in groups } \\
\hline$<30$ years & $115(15.7)$ & $21(19.4)$ & 0.359 & NA \\
\hline $30-39$ years & $316(43.2)$ & $37(34.3)$ & & \\
\hline $40-49$ years & $195(26.6)$ & $33(30.6)$ & & \\
\hline$\geq 50$ years & $106(14.5)$ & $17(15.7)$ & & \\
\hline \multicolumn{5}{|l|}{ Gender } \\
\hline Male & $169(84.9)$ & $30(15.1)$ & 0.285 & NA \\
\hline Female & $563(87.8)$ & $78(12.2)$ & & \\
\hline \multicolumn{5}{|l|}{ Education of respondent } \\
\hline No formal education & $40(5.5)$ & $4(3.7)$ & 0.545 & NA \\
\hline Primary Education & $266(36.3)$ & $46(42.6)$ & & \\
\hline Secondary Education & $317(43.3)$ & $45(41.7)$ & & \\
\hline Tertiary Education & $109(14.9)$ & $13(12.0)$ & & \\
\hline \multicolumn{5}{|c|}{ Employment status of respondent } \\
\hline Self employed & $545(87.5)$ & $78(12.5)$ & 0.725 & NA \\
\hline Salary earners & $101(84.9)$ & $18(15.1)$ & & \\
\hline Unemployed/student & $86(87.8)$ & $12(12.2)$ & & \\
\hline \multicolumn{5}{|l|}{ Number of years on HAART } \\
\hline $1-4$ & $435(87.5)$ & $62(12.5)$ & 0.690 & NA \\
\hline$>4$ & 297 (86.6) & $46(13.4)$ & & \\
\hline \multicolumn{5}{|l|}{ Area of residence } \\
\hline Urban & $263(91.6)$ & $24(8.4)$ & 0.005 & $1.90[1.17-3.06]$ \\
\hline Rural & $469(84.8)$ & $84(15.2)$ & & 1 \\
\hline \multicolumn{5}{|l|}{ Socio-economic status } \\
\hline Low socio-economic status & $362(85.2)$ & $63(14.8)$ & 0.085 & $0.9[0.6-1.4]$ \\
\hline High socio-economic status & $370(89.2)$ & $45(10.8)$ & & 1 \\
\hline \multicolumn{5}{|l|}{ Alcohol intake } \\
\hline No & $652(89.1)$ & $99(91.7)$ & 0.413 & NA \\
\hline Yes & $80(10.9)$ & $9(8.3)$ & & \\
\hline \multicolumn{5}{|l|}{ Cigarette/Tobacco Intake } \\
\hline No & $717(98.0)$ & $106(98.1)$ & 0.892 & NA \\
\hline Yes & $15(2.0)$ & $2(1.9)$ & & \\
\hline \multicolumn{5}{|l|}{ Traditional Medicine intake } \\
\hline No & $689(94.1)$ & $103(95.4)$ & 0.603 & NA \\
\hline Yes & $43(5.9)$ & $5(4.6)$ & & \\
\hline \multicolumn{5}{|c|}{$\begin{array}{l}\text { Cost of transportation to health } \\
\text { facility (Naira) }\end{array}$} \\
\hline$\leq 400$ & $402(57.1)$ & $58(55.8)$ & 0.798 & NA \\
\hline$>400$ & $302(42.9)$ & $46(44.2)$ & & \\
\hline \multicolumn{5}{|c|}{ Baseline CD4 staging (cells/ $\mu \mathrm{L})$} \\
\hline $0-199$ & $306(41.8)$ & $55(50.9)$ & 0.029 & $0.39[0.14-1.12]$ \\
\hline $200-349$ & $252(34.4)$ & $41(38.0)$ & & $0.45[0.15-1.30]$ \\
\hline $350-499$ & $111(15.2)$ & $8(7.4)$ & & $0.98[0.28-3.39]$ \\
\hline$\geq 500$ & $63(8.6)$ & $4(3.7)$ & & 1 \\
\hline
\end{tabular}

respondents were self-employed $(74.2 \%)$ and there was a greater proportion of respondents residing in rural areas (65.8\%). More than 50\% ofrespondents (497) had been on HAART for less than 4 years. Furthermore, there were more respondents on a first line regimen $(80.4 \%$ ) than those on a second line regimen $(19.6 \%)$. When defined by a CD 4 count $<200$ cells $/ \mu 1,43 \%$ of our study participants $(n=361)$ had AIDS. Our analysis identified that there was good adherence to anti-retroviral treatment in $89.5 \%$ (752) of the respondents (Table 2). Approximately 87\% (732) of respondents were found to have adequate retention. Male respondents were twice as likely to adhere to their 
ART than their female counterparts though the difference in proportion was not found to be statistically significant (adjusted odds ratio [AOR]: 2.08; 95\% confidence interval [CI]: 1.12-3.85) $\mathrm{p}=0.199$ (Table 3). Respondents on HAART for more than 5 years were also twice as likelyto achieve adherence when compared with those who had taken HAART for less than 5 years and the difference in proportion was statistically significant (AOR: 1.92; 95\% CI: $1.17-3.16) \mathrm{p}=0.023$. Similarly, respondents who did not take alcohol had approximately four times the odds of being adherent to their medications when compared to those who did use alcohol. There was a statistically significant difference in this proportion (AOR 3.67, 95\% CI: 2.01-6.70) $\mathrm{p}<0.001$. Those who did not consume traditional medicine were approximately three times more likely to have better adherence than those who did consume traditional medicine (AOR: 2.76; 95\% CI: 1.33-5.73) p <0.001. Respondents with a baseline CD 4 count $>500$ cells $/ \mu$ l were approximately six times more likely to be adherent when compared with those having a baseline CD 4 count $<200$ cells / $\mu$ l (AOR: 5.67; 95\% CI:1.32-24.32). The difference in proportion was statistically significant $(p=0.041)$. Participants who resided in urban areas were approximately twiceas likely to show adequate retainment as those who resided in rural areas (AOR: 1.90; 95\% CI: 1.17-3.06) This was statistically significant $(\mathrm{p}=0.005)$ (Table 4). Comparable proportion of participants who had low SES had approximately one time the odds of being adequately retained than those with high SES (AOR: 0.90; 95\% CI: 0.62-1.46) $\mathrm{P}=0.085$. The respondents with baseline CD $4<200$ cells / $\mu$ l were three times less likely to be adequately retained when compared with their counterparts having baseline CD4 >500 cells/ $\mu$ l (AOR: 0.39; 95\% CI: $0.14-1.12$ ) and the difference in proportions was found to be statistically significant $(p=0.029)$. The commonest reasons for missing medication were being away from home (41.8\%) and forgetfulness $(35.0 \%)$. Other reasons included physical discomfort (6.8\%), running out of medication $(12.6 \%)$, could not hide to take the drugs (2.4\%) and fasting (1.4\%) (Figure 1).

\section{Discussion}

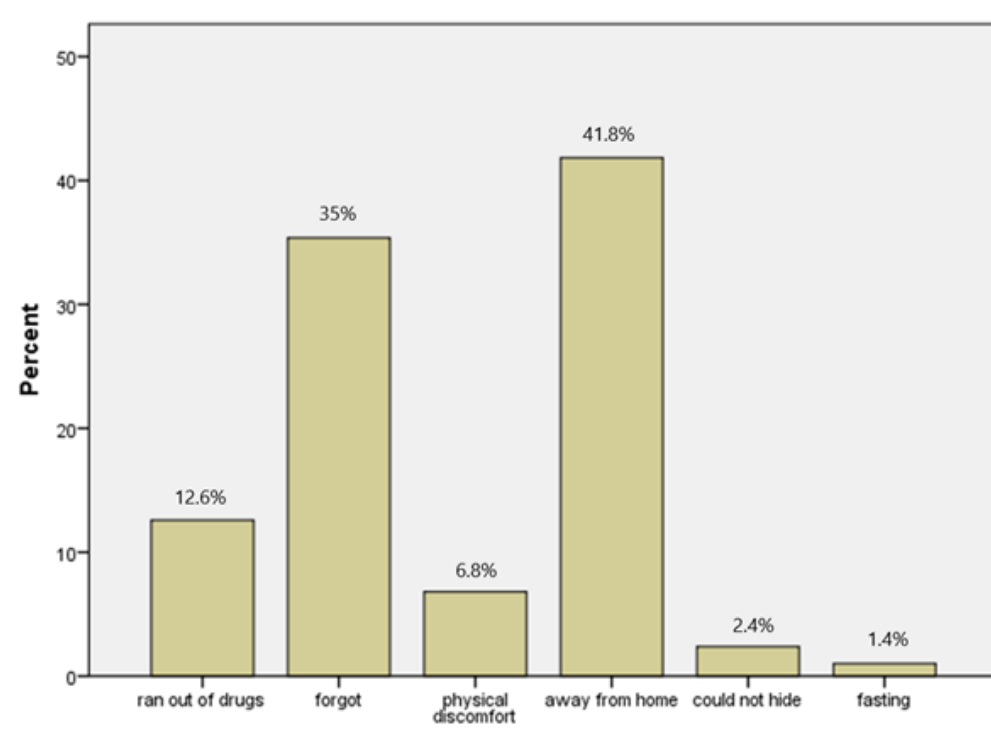

Figure 1. Reasons for missed medications ( $=294)$

The WHO reports that approximately one-third of patients suffering from HIV/AIDS take their medication as prescribed $^{24}$.However, this remains a significant challenge for patients living in both developed and developing countries.
The self-reported adherence to ART in this study was $89.5 \%$, slightly higher than the $85.8 \%$ that was previously reported in Nnewi, another city in south-east Nigeria ${ }^{25}$. Seven years ago, when ART programs were only just being developed in our study area, the level of adherence was as low as $75 \%{ }^{5}$. This may possibly have been due to the lack of drugsin several health facilities during this period of time. Thus, inconsistent access to medications could have presented a challenge to the delivery system and unwittingly encouraged non-adherence. However, with enhanced availability and accessibility to medications, as well as the provision of free ART services, it is evident that adherence has improved significantly in this region. The results of our study were consistent with previous findings from some other developing African countries, where a high rate of adherence (based on self-reporting) has also been reported, including Ghana $(86 \%)^{26}$, Rwanda $(77 \%)^{27}$ and Ethiopia $(95 \%)^{28}$. Interestingly, this finding is in direct contrast to a previous WHO report which stated that themean adherence rate to long-term therapy for chronic illnesses in developed countries was approximately $50 \%$, and that in developing countries, the rates were even lower ${ }^{24}$.

We found that being away from home and forgetfulness were reported as the major reasons for missing medication; similar factors were noted in some other studies ${ }^{29,30}$. Other, less frequently reported reasons for missed doses included stock control problems for drugs, discomfort/side effects, being ashamed of taking medication in front of others and fasting. The retention of PLHIV on ART in this study $(87.1 \%)$ was higher than the $82.6 \%$ and $66.5 \%$ previously reported in private and public facilities in South-East Nigeria, respectively ${ }^{21}$. Previous retrospective studies of Nigeria, carried out over 7 (2005-2012) and 5 years (2009-2013), showed retention ratesof $63 \%$ and $76.1 \%$, respectively ${ }^{14,31}$. Based on these findings, we can therefore infer that although patients are still LTFU, and there is clear potential for the development and transmission of drug-resistant strains of HIV, there has been a progressive improvement in the rate of retention in Nigeria. However, the approach of measuring retention in these retrospective studies focused on only one or more visits to the clinic each yearand could therefore overestimate the level of retention as patients LTFU would not have been included. A similar progressive increase in retention has been documented in Ethiopia, where the retention rate has risen from $77 \%$ (2004-2005) to $92 \%(2012-2013)^{13}$. These progressive increases in retention rates could be due to the massive scale-up of HIV services and recent intervention programs aimed at improving retention in these countries.

Our bivariate analyses revealed that there was a statistical association between adherence to medication and gender, the number of years on HAART, alcohol intake, the intake of traditional medicine and baseline CD 4 cell count. The finding that men were more likely to adhere to their medication than women is a true reflection of gender issues in sub-Saharan Africa as African men are generally seen to have more"free" time and money at their disposal than women ${ }^{32}$. This finding was similar to a previous study carried out in south-east Nigeria, which found that females were less adherent to their medications due to forgetfulness, poor communication and the side effects of drugs ${ }^{19}$. Furthermore, due to cultural barriers, women in our study setting may have had difficulties disclosing their status, thus meaning that they 
needto hide while taking their medications.

Patients who have been on HAART for a longer duration would have been exposed to the relative advantages and disadvantages of adhering to their medicationas they would have witnessed treatment failure and possibly the death of non-adherent patients. Poor adherence rates among those who have been on HAART for short durations could also be the result ofanti-retroviral-related toxicity experienced when the medication was first introduced. This significant finding implies that adherence improves over longer durations of treatment.Similar findings were described for Botswana, where patients who had been receiving ART for the shortest duration of time (1-6 months) had the poorest adherence to medication ${ }^{33}$. However, a conflicting finding was reported for HIV-positive pregnant women in south-east Nigeria; in this particular cohort of patients, there was a lower rate of adherence reported for those who had been on HAART for long periods of time ${ }^{34}$. This finding was attributed to complacency, especially among long-term patients who saw clear improvements in theirphysical and psychological function. This may have reduced their motivation to adhere to anti-retroviral medications after delivery. Our study further showed that patients who took alcohol and traditional medicine showed poor adherence to their medications. The association between alcohol intake and adherence has been documented in previous studies ${ }^{35}$. In contrast to our present findings, drinking alcohol was not associated with nonadherence to antiretroviral therapy in a study carried out in Ethiopia $^{36}$. This inconsistency could represent socio-cultural differences in the two different study settings. Although the intake of traditional concoctions has been reported as a barrier to ART adherence, PLHIV on anti-retrovirals in South Africa still ingest these concoctions, which are sourced from traditional healers, while adhering to their ART, as they are reported to act as an internal body cleanser ${ }^{37}$.

In most resource-limited countries of Africa, where most of the world's HIV-infected people live, the diagnosis of HIV infection is often made during advanced stages when AIDS-defining illnesses begin to manifest ${ }^{38}$. It is therefore not surprising that a CD4 count $<200$ cells could predict adherence to medication in this study; $43 \%$ of patients presented with a CD4 count $<200$ cells at baseline. Similarly, other studies have reported that patients with CD 4 counts $>200$ cells at the beginning of ART were at a higher risk of non-adherence ${ }^{7,39}$. These patients probably deem themselves to be healthy and therefore decided not to carry on with their medications. Retaining PLHIV has the potential not only to limit health care costs but also to provide the opportunity to implement preventive health care interventions. This may promote behavioural changes in healthcare, thus leading to a reduction in HIV transmission and burden, thus leading to a general improvement in public health ${ }^{40}$.We found that the area of residence was a significant predictor of retention in our present study. Patients residing in rural areas might have difficulties accessing health facilities. This is because more health facilities offer HIV treatment services in urban areas than rural areas, thus making it difficult for those in rural areas to access care. Distance to the clinic, as well as travel times that exceed 2 hours due to bad roads, or financial constraints, have also been identified as major barriers to retention in previous studies ${ }^{14,40}$.

\section{Conclusion}

The rate of adherence to medication and retention-in-care was higher in our study area than other studies conducted in Nigeria. Gender, the number of years on HAART, alcohol intake and the intake of traditional medicine predicted non-adherence to medication while residence in urban areas predicted retention. While some of these factors are modifiable, others are not. Based on this study,we recommend that to achieve good adherence and adequate retention, programs and research should focus on interventions that can particularly improve adherence among females and lead to behavioural modifications whichcan reduce the intake of alcohol and traditional medications in the study area. These practices will invariably improve the adherence to ART in this region. Although the level of adherence to medication among PLHIV is increasing insouth-east Nigeria, there is a need for sustained improvement to ensure optimal health outcomes. A decline in adherence has been projected in resource-limited settings as treatment access increases. Although the number of available treatment facilities continues to increase in this setting, patients may continue to avoid accessing care from facilities within their communities because of stigma. Consequently, the scale-up of treatment facilities must be coupled with social support from the community. Our findings also support the need to evaluate access to health facilities based on their localities to ascertain measures to specifically support patients in rural settings.

\section{Limitations}

There is no gold standard for measuring adherence. In the present study, we based adherence only by analysing the self-reporting of missed doses over a period of 28 days. It is possible that this may be affected by recall bias and overestimation $^{7}$.The use of more objective measures, such as a microelectronic monitoring system for pill counts, would have provided a more comprehensive assessment of adherence than self-reporting. However, a simple self-report adherence questionnaire, such as the one used in this study, has previously been reported to provide a profound degree of non-adherence that predicts viral rebound and is almost always reliable7.Finally, the exclusion of patients who have been on HAART for less than a year, as well as patients in HIV clinical stage 3 and 4, may also affect the generalization of the findings of this study.

\section{Acknowledgments}

We would like to thank thePLHIV who agreed to participate, and the healthcare workers in the respective health facilities, including the peer support group coordinators, for their efforts and co-operation.

\section{Conflicts of interest}

The authors have no conflicts of interest to declare.

\section{Funding}

The researchers did not receive a specific grant from funding agencies in the public, commercial or not for profit sectors.

\section{Ethical considerations}

Ethical approval for this study was obtained from the Health Research and Ethics Committee of Enugu State University Teaching Hospital (ESUTH) Enugu, Nigeria.Approval was also obtained from the Enugu State Ministry of Health and the management of the selected health facilities. Written informed consentwas obtained from each of the participants.

\section{Availability of data and materials}

Materials and data are available from the Department of https://dx.doi.org/10.4314/mmj.v31i3.7 
Community Medicine, Enugu State University Teaching Hospital for a period of 5 years following publication.

\section{Authors' contributions}

OC conceived, designed and drafted this study. CO analysed and interpreted the data, while EN provided administrative and technical support. All authors critically revised the manuscript and approved the final version for publication.

\section{References}

1. World Health Organization (WHO).HIV/AIDS Data and Statistics WHO | World Health Organization. 2017 [cited 2018 Jan 29]. Available from:https://www.who.int/hiv/data/en/.

2. Averting HIV and AIDS (AVERT). HIV and AIDS in Nigeria. [Internet]. 2017 [cited 2018 Feb 4].Available from: https://www.avert. org/professionals/hiv-around-world/sub-saharan-africa/nigeria

3. Tarimo EAM, George J. Providing anti-retroviral therapy in the context of self-perceived stigma: a mixed methods study from Tanzania. Tanzan J Health Res. 2014;16:1-12. DOI: 10.4324/thrb.v16i2.3.

4. Simoni JM, Nelson KM, Franks JC, Yard SS, Lehavot K. Are peer interventions for HIV efficacious? Asystematic review. AIDS Behav. 2011;15:589-95.DOI: 10.1007/s10461-011-9963-5.

5. Uzochukwu BSC, Onwujekwe OE, Onoka AC, Okoli C, Uguru NP, Chukwuogo OI. Determinants of non-adherence to subsidized anti-retroviral treatment in southeast Nigeria. Health Policy Plan. 2009;24:189-196.DOI:10.1093/heapol/czp006.

6. Steel G, Joshi M, Paige S. Antiretroviral therapy adherence measurement and support in South Africa: initial activities from July 4 to 26, 2005. Submitted to the U.S. Agency for International Development by the Rational Pharmaceutical Management Plus Program. Arlington, VA. Manag Sci Health.205;1-12.

7. Machtinger EL, Bangsberg DR. Adherence to HIV antiretrovira therapy. HIV in-site knowledge base chapter. Comprehensive, up-todate information on HIV/AIDS treatment and prevention from the University of California San Francisco [Internet]. May 2005 [content reviewed January 2006; cited 2018 Jan 12]. Available from:http:// hivinsite.ucsf.edu/InSite

8. World Health Organisation. Towards universal access: scaling up priority interventions in the health sector; progress report. 2007. Geneva: WHO. [cited 2018 Feb 01]. Available from: https://www.who. int/hiv/mediacentre/universal_access_progress_report_en.pdf

9. Amberbir A, Woldemichael K, Getachew S,Girma B,Deribe K. Predictors of adherence to antiretroviral therapy among HIV-infected persons: a prospective study in Southwest Ethiopia.BMC Public Health. 2008;8:265. DOI: 10.1186/1471-2458-8-265

10. Boruett P, Kagai D, Njogo S, Nguhiu P, Awuor C, Gitau L, et al. Facility-level intervention to improve attendance and adherence among patients on anti-retroviral treatment in Kenya-a quasi-experimental study using time series analysis. BMC Health Serv Res. 2013;13: 242. DOI: $10.1186 / 1472-6963-13-242$.

11. Mills EJ, Nachega JB, Buchan I, Orbinski J, Attaran A, Singh S, et al. Adherence to antiretroviral therapy in sub-Saharan Africa and North America: a meta-analysis. JAMA. 2006;296:679-90. DOI: 10.1001/ jama.296.6.679

12. Fox MP, Rosen S. Patient retention in antiretroviral therapy programs up to three years on treatment in sub-Saharan Africa, 20072009: systematic review. Trop Med Int Health. 2010; 15(Supp 1):1-15. DOI: $10.1111 / \mathrm{j} .1365-3156.2010 .02508 . x$.

13. AssefaY,Alebachew A,Lera M,Lynen L,Wouters E,Van Damme W. Scaling up antiretroviral treatment and improving patient retention in care: lessons from Ethiopia, 2005-2013.Global Health. 2014; 10:43 DOI: $10.1186 / 1744-8603-10-43$.

14. Eguzo K, Lawal A, Umezurike C, Eseigbe C. Predictors of loss to follow-up among HIV-infected patients in arural South-Eastern Nigeria hospital: a 5-year retrospective cohort study.Ann Med Health Sci Res. 2015;5(6):373-8. DOI:10.4103/2141-9248.177988.

15. Rosen S, Fox MP, Gill CJ. Patient retention in antiretroviral therapy programs in Sub-Saharan Africa: a systematic review. PLoS Med. 2007;4:e298. DOI:10.1371/journal.pmed.0040298.

16. Omosanya OE, Elegbede OT, Agboola SA, Isinkaye AO, Omopariola OA. Effects of stigmatization/discrimination on antiretroviral therapy adherence among HIV-infected patients in a rural tertiary medical centre in Nigeria. J IntAssocProvid AIDS Care. 2014;13:260-3.DOI: $10.1177 / 2325957413475482$

17. Olowookere SA, Fatiregun AA, Akinyemi JO, Bamgboye AE, Osagbemi GK. Prevalence and determinants of nonadherence to highly active antiretroviral therapy among people living with HIV/AIDS in Ibadan, Nigeria.J Infect Dev Ctries. 2008;2:369-72.DOI: 10.3855/ jidc. 199 .

18. RedaAA,Biadgilign S. Determinants of adherence to antiretroviral therapy among HIV-infected patients in Africa. AIDS Res Treat. 2012;2012:574656.DOI: 10.1155/2012/574656.

19. Okoronkwo I, Okeke U, Chinweuba A, Iheanacho P. Nonadherence factors and sociodemographic characteristics of HIV-infected adults receiving antiretroviral therapy in NnamdiAzikiwe University Teaching Hospital, Nnewi, Nigeria. AIDS. 2013;2013:843794. DOI: $10.1155 / 2013 / 843794$

20. Odafe S, Torpey K, Khamofu H, Ogbanufe O, Oladele EA, Kuti $\mathrm{O}$, et al. The pattern of attrition from an antiretroviral treatment program in Nigeria. PLoS One. 2012;7:e51254. DOI:10.1371/journal. pone. 0051254 .

21. Onoka CA, Uzochukwu BS, Onwujekwe OE, Chukwuka C, Ilozumba J, Onyedum C, et al. Retention and loss to follow-up in antiretroviral treatment programmes in southeast Nigeria.Pathog Glob Health. 2012;106:46-54. DOI:10.1179/2047773211Y.0000000018.

22. National Population Commission (NPC).2006 Population and housing census of Federal Republic of Nigeria: National and State Population Tables (Priority Tables) Vol. 1. Abuja, Nigeria; 2009.p.1.

23. Araoye MO. Research methodology with statistics for health and social sciences 1st ed. Nathadex:Ilorin; 2004. p. 120.

24. World Health Organization. Adherence to long-term therapies: evidence for action [Internet]. 2003. Geneva, Switzerland: WHO. [cited 2017 Dec 08]. Available from: https://www.who.int/chp/knowledge/ publications/adherence_report/en/.

25. Onyeonoro UU, Ebenebe UE, Ibe CC, Nwamoh UN, Ukaegbu AU. Adherence to antiretroviral therapy among people living with human immunodeficiency virus/acquired immunodeficiency syndrome in a tertiary health facility in Southeastern Nigeria.J HIV Hum Reprod. 2013;1:58-63.DOI: 10.4103/2321-9157.12663.

26. Obirikorang C, Selleh P, Abledu J, Fofie C. Predictors of adherence to antiretroviral therapy among HIV/AIDS patients in the upper west region of Ghana. ISRN AIDS. 2013:1-7.DOI:10.1155/2013/873939.

27. Elul B, Basinga P, Nuwagaba-Biribonwoha H, Saito S, Horowitz $\mathrm{D}$, Nash D, et al. High levels of adherence and viral suppression in a nationally representative sample of HIV-infected adults on antiretroviral therapy for 6, 12 and 18 months in Rwanda. PLoS One. 2013;8:e53586. DOI:10.1371/journal.pone.0053586.

28. Tiyou A,Belachew T,Alemseged F, Biadgilign S. Predictors of adherence to antiretroviral therapy among people living with HIV/ AIDS in a resource-limited setting of southwest Ethiopia. AIDS Res Ther. 2010;7:39.DOI:10.1186/1742-6405-7-39.

29. Maduka O, Tobin-West CI. Barriers to HIV treatment adherence: findings from a treatment center in South-South Nigeria. Int J Trop Dis Health. 2015;4:1233-44. DOI: 10.9734/ijtdh/2014/12186.

30. Chesney MA, Ickovics JR, Chambers DB, Gifford AL, Neidig J, Zwickl B, et al. Patient care committee \& adherence working group of the outcomes committee of the adult AIDS clinical trials group 
(AACTG). Self-reported adherence to antiretroviral medications among participants in HIV clinical trials: The AACTG Adherence Instruments. AIDS Care. 2010;12:255-266. DOI: 10.1080/09540120050042891.

31. Oluwole BA, Olujide JO, Oladele AA, Ekpo DS, AdebusuyiOO,Olaniyan TO, et al. Seven-year review of retention in HIV care and treatment in federal medical center Ido-Ekiti. Pan Afr Med J. 2015;22:139.DOI:10.11604/pamj.2015.22.139.4981.

32. Tumwikirize S, Torpey K, Adedokun O, Badru T. The value of support group participation in influencing adherence to antiretroviral treatment among people living with human immunodeficiency virus (HIV). World JAIDS. 2015;5:189-98. DOI: 10.4236/wja.2015.53022.

33. Kalichman SC, Ntseane D, Nthomang K, Segwabe M, Phorano O, Simbayi, LC. Recent multiple sexual partners and HIV transmission risks among people living with HIV/AIDS in Botswana. Sex Transm Infect. 2007;83:371-5.DOI: 10.1136/sti.2006.023630.

34. Igwegbe AO, Ugboaja JO,Nwajiaku LA. Prevalence and determinants of non-adherence to antiretroviral therapy among HIVpositive pregnant women in Nnewi, Nigeria. Int $\mathrm{J}$ Med Med Sci. 2010;2:238-45.

35. Boyer S, Clerc I, Bonono CR, Marcellin F, Bilé PC,Ventelou B.Non-adherence to antiretroviral treatment and unplanned treatment interruption among people living with HIV/AIDS in Cameroon: individual and healthcare supply-related factors. SocSci Med. 2011;72(8): 1383-92.DOI: 10.1016/j.socscimed.2011.02.030.

36. Dibaba B, Hussein M. Factors associated with non-adherence to antiretroviral therapy among adults living with HIV/AIDS in Arsi Zone, Oromia. J AIDS Clin Res. 2017;8:647. DOI:10.4172/21556113.1000647.

37. Wanyama J, Castelnuovo B, Wandera B, et al. Belief in divine healing can be a barrier to antiretroviral therapy adherence in Uganda. AIDS. 2007;21:1486-7. DOI:10.1097/QAD.0b013e32823ecf7f.

38. Allam RR, Murhekara MV, Bhatnagar T, Uthappa CK, Chava N, Rewari BB, et al. Survival probability and predictors of mortality and retention in care among patients enrolled for first-line antiretroviral therapy, Andhra Pradesh, India, 2008-2011. Trans R Soc Trop Med Hyg. 2014;108:198-205. DOI:10.1093/trstmh/tru025.

39. Charurat M, Oyegunle M, Benjamin R, Habib A,Eze E, Ele P. Patient Retention and Adherence to Antiretrovirals in a Large Antiretroviral Therapy Program in Nigeria: a longitudinal analysis for risk factors. PLoS One. 2010;5:e10584. DOI:10.1371/journal.pone.0010584.

40. Horstmann E, Brown J, Islam F, Buck J, Agins BD. Retaining HIVinfected patients in care: where are we? where do we go from here? Clin Infect Dis. 2010;50(5):752-61.DOI: 10.1086/649933. 